International Journal of Current Advanced Research

ISSN: O: 2319-6475, ISSN: P: 2319 - 6505, Impact Factor: SJIF: 5.995

Available Online at www.journalijcar.org

Volume 6; Issue 3; March 2017; Page No. 2813-2814

DOI: http://dx.doi.org/10.24327/ijcar.2017.2814.0113

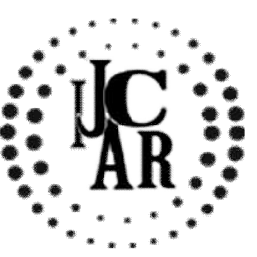

Research Article

\title{
ORAL MANIFESTATIONS ARISING IN RHEUMATIC FEVER
}

\section{R.Jagadish Rajkumaar and Dhanaraj}

Department of prosthodontics Saveetha Dental College and Hospitals Chennai-600 077

\section{A R T I C L E I N F O}

\section{Article History:}

Received $26^{\text {th }}$ December, 2016

Received in revised form $10^{\text {th }}$ January, 2017

Accepted $5^{\text {th }}$ February, 2017

Published online $28^{\text {th }}$ March, 2017

\section{Key words:}

Rheumatic Fever, Oral Manifestations \begin{abstract}
A B S T R A C T
Topic : To assess and knowledge and awareness among the dental students about the oral manifestations arising in rheumatic fever.

Aim : To do a survey and find out the knowledge regarding the oral manifestations arising in rheumatic fever among the dental students.

Objective : Since many dental students may not be fully aware about the oral manifestations in rheumatic fever.Hence a survey is conducted to help people understand better about the disease.

Background : Very rare problem arising in the throat,Fewer than 100 thousand cases per year,Rheumatic fever causes inflammation, especially of the heart, blood vessels, and joints.The Symptoms include fever and painful, tender joints.Treatment involves medication.

Reason: To evaluate and gain information among the dental students about their awareness about the oral manifestations of rheumatic fever.
\end{abstract}

Copyright $₫ 2017$ R.Jagadish Rajkumaar and Dhanaraj. This is an open access article distributed under the Creative Commons Attribution License, which permits unrestricted use, distribution, and reproduction in any medium, provided the original work is properly cited.

\section{INTRODUCTION}

Rheumatic fever is one of the complications associated with strep throat. [1] It's a relatively serious illness that can cause stroke, permanent damage to your heart, and death if it's left untreated.Rheumatic fever is caused by [2] group A streptococcus. This bacterium causes strep throat or, in a small percentage of people, scarlet fever. [3] Its an inflammatory disorder.Rheumatic fever causes your body to attack its own tissues after it's been infected with the bacteria that causes strep throat. This reaction causes [11] widespread inflammation throughout your body, which is the [4] basis for all of the symptoms of rheumatic fever. Dental practitioners are more likely to be involved in dental treatment of patients with cardiac diseases. Dental manipulations including [5] oral surgery, periodontal procedures and root canal therapy can lead to infection of sterile vegetations on cardiac valves in susceptible patients to endocarditis. The main consideration in their dental management of patients has been the [6] prerequisite of appropriate antibiotic prophylaxis (RF) when clinically indicated.so this study has been initiated to gain information about the knowledge of the oral manifestations of rheumatic fever among the dental students.

\section{MATERIALS AND METHODS}

A study was conducted among 100 dental college students by

*Corresponding author: R.Jagadish Rajkumaar

Department of prosthodontics Saveetha dental college and hospitals Chennai-600 077 a survey containing 15 questions and prior to this the students were given a brief overview about the disease rheumatic fever and its effects and then they were given time to give their responses and by the help of the data collected the result was concluded.

\section{RESULT}

So in this study the following results were obtained only $46 \%$ of the students were aware about the causative agent which caused rheumatic fever.53\% of the students were not about the fact that rheumatic fever cause damage to the heart by endocarditis 53\% students were not aware that rheumatic fever caused ulcerations in the oral cavity and rashes on the skin. As many dental students were not aware about the symptoms of the disease awareness is much needed and it can be achieved by conducting conferences and surveys.

\section{DISCUSSION}

Rheumatic fever usually starts off with a sore throat and the [7] sore throat with tender and swollen lymphnodes. Symptoms appear between one and five weeks after a sore throat, with an average of three weeks.In recurrent cases this incubation period is shorter, in keeping with a faster immune response.The diagnosis is based on major and minor criteria. In the acute disease the arthritis and toxicity are obvious but it can be more insidious with mild carditis. This probably accounts for only about half of those with typical rheumatic heart disease giving a history of RF. It causes [8] red rashes on the skin and difficulty while swallowing food.It 

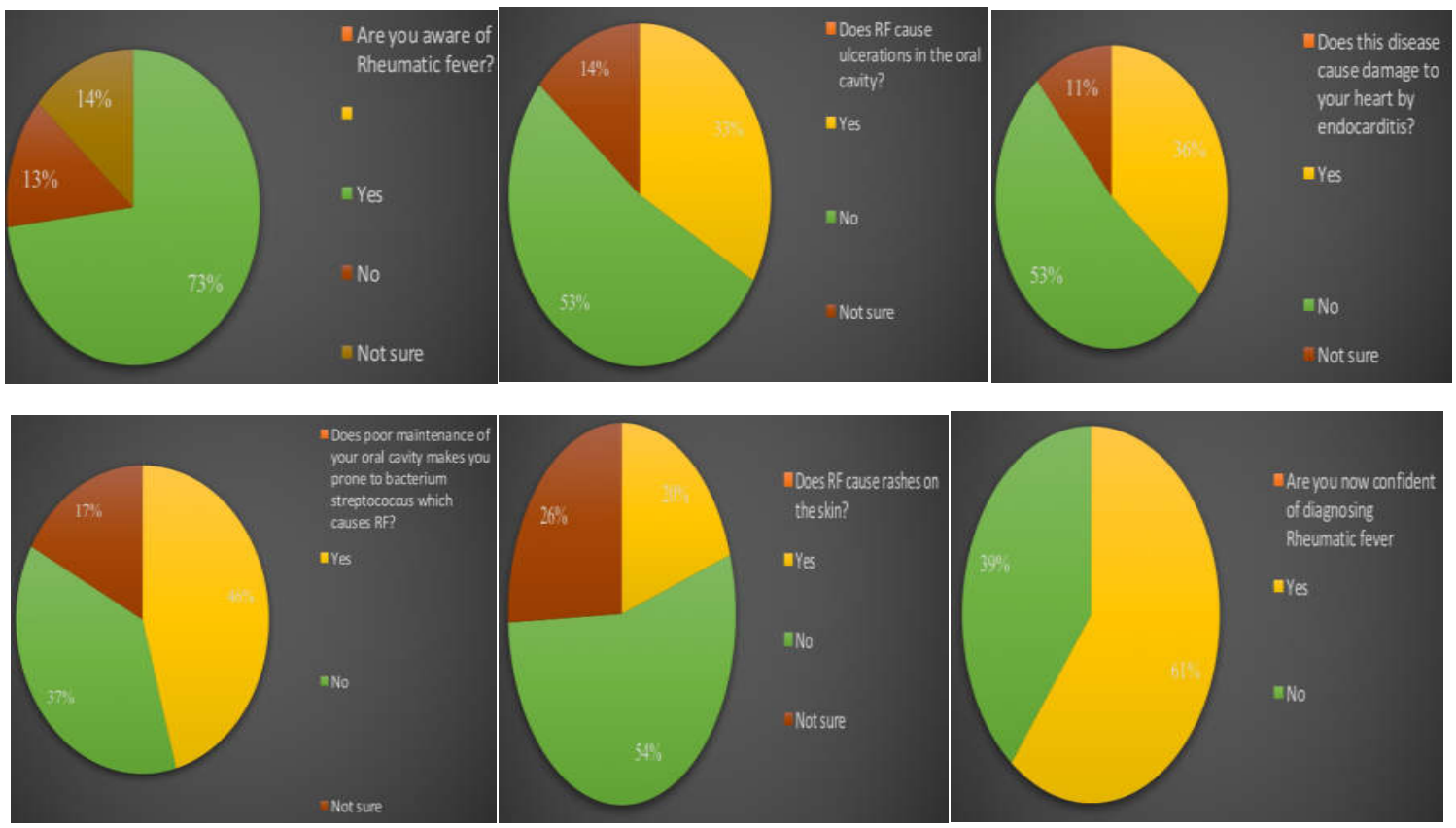

causes thick, bloody discharge from nose with a temperature of $101^{\circ} \mathrm{F}$ or above and tonsils that are red and swollen with white patches or pus. It even causes small, [9] red spots on the roof of their mouth and the usual symptoms are headache, nausea, vomiting. Though it has a lot of general manifestations its oral manifestations are the [10] primary symptoms which can be seen clearly in the initial stages of disease which can be diagnosed by a dentist who is into the job of looking into the oral cavity whenever a patient comes to him with a problem in his/her oral cavity. It must be remembered that dentists have a rare opportunity to detect cases of Rheumatic fever. So it is essential for a dentist who has to ensure the patients oral hygiene to know about the oral manifestations caused by the rheumatic fever and alert the patient for further diagnosis or treatment.

\section{CONCLUSION}

The study demonstrates that inadequate attention is paid to the maintenance of good oral health in patients with severe rheumatic heart disease. It is very likely that within our healthcare system, the oral health of patients with less severe rheumatic heart disease who are not attending specialist cardiac facilities is also suboptimal. This important aspect of the prevention of infective endocarditis or rheumatic fever needs greater attention.

\section{References}

1. Smith AJ, Adams D. The dental status and attitudes of patients at risk from infective endocarditis. $\mathrm{Br}$ Dent J. 1993; 174: 59-64. [PubMed]

2. Cameron IW. Subacute bacterial endocarditis in an edentulous patient. A case report. Br Dent J. 1971; 130:404-406. [PubMed]
3. Croxson MS, Altmann MM, O’Brien KP. Dental status and recurrence of streptococcus viridans endocarditis. Lancet. 1971;i: 1205-1207. [PubMed]

4. Simon DS, Goodwin JF. Should good teeth be extracted to prevent streptococcus viridans endocarditis? Lancet. 1971;i: 1207-1209. [PubMed]

5. Balmer R, Bu'Lock FA. The experiences with oral health and dental prevention of children with congenital heart disease. Cardiol Young. 2003; 13:439-443. [PubMed]

6. Rai K, Supriya S, Hegde AM. Oral health status of children with congenital heart disease and the awareness, attitude and knowledge of their parents. $J$ Clin Pediatr Dent. 2009; 33:315-318. [PubMed]

7. Balmer R, Booras G, Parsons J. The oral health of children considered very high risk for infective endocarditis. Int J Paediatr Dent. 2010; 20:173-178. [PubMed]

8. Wilkins EM. Clinical Practice of the Dental Hygienist. 5th edn. Philadelphia: Lea \& Febiger; 1983. pp. 299-301.

9. Finkelstein MB, Lownie JF, Cleaton-Jones PE. Pathological conditions detected on panoramic radiographs of two Johannesburg populations. J Dent Assoc S Afr. 1988; 43:111-114. [PubMed]

10. Kerr DA, Ash MM., Jr. Oral Pathology. 4th edn. Philadelphia: Lea \& Febiger; 1978.

11. ThomAR, Howe GL. The dental status of cardiac patients. Br Heart J. 1972; 34:1302-1307. [PMC free article] [PubMed]

12. Holbrook WP, Willey RF, Shaw TR. Dental health in patients susceptible to infective endocarditis. $\mathrm{Br}$ Med J. 1981; 283:371-372. [PMC free article] [PubMed]

\section{Please cite this article in press as:}

R.Jagadish Rajkumaar and Dhanaraj (2017), Oral Manifestations Arising In Rheumatic Fever, International Journal of Current Advanced Research, 6(3), pp. 2813-2814. http://dx.doi.org/10.24327/ijcar.2017.2814.0113 